\title{
PENGEMBANGAN MEDIA FLASHCARD BERBASIS MACROMEDIA FLASH PADA PEMBELAJARANBAHASA INDONESIA MODEL THINK TALK WRITE UNTUK MENINGKATKAN KEMAMPUAN MENULIS SISWA KELAS IV SEKOLAH DASAR
}

\author{
Desi Eka Pratiwi' ${ }^{1}$, Bambang Yulianto ${ }^{2}$, Suhartono ${ }^{3}$ \\ Pendidikan Dasar Pascasarjana Unesa, Universitas Negeri Surabaya
}

\begin{abstract}
Abstrak
Penelitian ini bertujuan untuk meningkatkan kemampuan menulis siswa kelas IV sekolah dasar melalui pengembangan media flashcard berbasis macromedia flash Pada Pembelajaran Bahasa Indonesia model Think Talk Write untuk Siswa Kelas IV Sekolah Dasar.

Data hasil penelitian yang diperoleh adalah sebagai berikut: validasi isi ahli ke SD an mendapatkan skor 91,07 $\%$; Validasi suara ahli Bahasa mendapatkan skor 87,5 \%; Validasi suara ahli teknologi pendidikan mendapatkan skor 93,75\%; Validasi Bahasa ahli Bahasa mendapatkan skor $90 \%$; Validasi gambar diam ahli teknologi pendidikan mendapatkan skor $93,75 \%$; Validasi gambar animasi ahli teknologi pendidikan mendapatkan skor $89,92 \%$. Sedangkan respons mendapatkan persentase $90 \%$ dengan kategori siswa sangat aktif. Respons guru mendapatkan persentase $90 \%$ dengan tingkat keberhasilan baik sekali/optimal. Persentase aktivitas siswa mendapatkan skor $91.66 \%$ dengan tingkat aktivitas siswa sangat aktif, dan guru mendapatkan persentase $90 \%$ dengan tingkat keberhasilan baik sekali/istimewa. Secara klasikal, tingkat keberhasilan siswa sebelum menggunakan media rata-rata nilai kelas 74.16 masih dibawah KKM. Sedangkan, tingkat keberhasilan siswa setelah menggunakan media rata-rata nilai kelas adalah 85.24. terdapat peningkatan sebanyak $20 \%$.

Berdasarkan hasil analisis data, dapat disimpulkan bahwa pengembangan media flashcard berbasis macromedia flash pada pembelajaran Bahasa Indonesia model Think Talk Write efektif untuk meningkatkan kemampuan menulis siswa, namun masih memerlukan penyempurnaan pada penelitian-penelitian selanjutnya.
\end{abstract}

Kata-kata kunci: Media Flashcard Berbasis Macromedia flash, Model Think Talk Write, Kemampuan Menulis.

\begin{abstract}
The purpose of this study to improve students' writing skill on the $4^{\text {th }}$ grade elementary school students through flashcard media development macromedia flash basis on Indonesia subject think talk write model for student on the $4^{\text {th }}$ grade elementary school students.

The result of this study as following: the score from expert to content validity was 91, 07\%; the score from language expert was 87, 5\%; the score from education technology expert was 93, 75\%; the score from language validation from language expert was $90 \%$. Picture validation from education technology expert was $93,75 \%$. Animation picture validation from education technology expert was $89,92 \%$. While the response's score was $90 \%$ which students very active category. The score of teacher's response was $90 \%$ which successfully or optimally. The percentage of students' activity was $91,66 \%$ which students very active and teacher percentage was $90 \%$ which successfully. Classically the students achievement before use media were 74, 16\% under KKM. While, students' achievements after use media were $85,24 \%$, there was enhancement up to $20 \%$.

Based on the result of the data analysis could be concluded that the media development flashcard based macromedia flash in Indonesia subject model Think Talk Write were effective to increase students writing ability. Nevertheless still need improvement on the further research.
\end{abstract}

\section{PENDAHULUAN}

Sebagaian besar siswa tidak mampu menuangkan ide/gagasannya dalam bahasa tulis. Kemampuan menulis dianggap sebagai kemampuan yang paling sulit. Ketersediaan media pembelajaran di sekolah membantu dalam keterlaksanaan proses belajar mengajar. Salah satu jenis media yang mampu menjawab tantangan pada era teknologi dengan menggunakan multimedia. Menurut Zeembry (dalam Ariani, dkk. 2003:11) menyatakan bahwa multimedia merupakan kombinasi dari data teks, audio, gambar, animasi, video, dan interaksi.

Secara umum, media pembelajaran mempunyai kegunaan sebagai alat untuk memperjelas bahan pengajaran, serta dapat mengangkat atau menimbulkan persoalan untuk dikaji lebih lanjut dan dipecahkan oleh para siswa dalam proses belajarnya (Sudjana, dkk. 2005:6). kualitas suatu produk disesuaikan dengan hasil pengembangan yang dinyatakan oleh Nieveen (1999:123), yaitu (1) kevalidan (validity);(2) kepraktisan (practicity); (3) keefektifan 
(effectiveness). Indikator kevalidan bahan ajar menurut Nieveen (1999:127), meliputi dua hal yaitu (a) kekuatan teori dalam komponen bahan ajar/validaitas isi; (b) kekonsistenan secara internal pada semua komponen bahan ajar/validitas konstruk.

kualitas suatu produk disesuaikan dengan hasil pengembangan yang dinyatakan oleh Nieveen (1999:123), yaitu (1) kevalidan (validity);(2) kepraktisan (practicity);

keefektifan (effectiveness). Indikator kevalidan bahan ajar menurut Nieveen (1999:127), meliputi dua hal yaitu (a) kekuatan teori dalam komponen bahan ajar/validaitas isi; (b) kekonsistenan secara internal pada semua komponen bahan ajar/validitas konstruk.

Penelitian Terdahulu yang Relevan

Penelitian relevan sebelumnya pernah dilakukan oleh Miswanto pada tahun 2011. Penelitian tersebut difokuskan pada penggunaan media berbasis komputer dengan program macromedia flash pada pengembangan perangkat pembelajaran IPA SD pokok bahasan sistem tata surya. Selain Miswanto, penelitian serupa pernah dilakukan oleh Abdul Munif pada tahun 2013. Dalam penelitian tersebut difokuskan pada pengembangan media bintang kecil pada pembelajaran kosa kata Bahasa Indonesia kelas I SD dengan tema keluarga. Penelitian terbaru yang relevan dilakukan oleh Nur Izatil Hasanah pada tahun 2014. Penelitian ini difokuskan pada pengembangan Permainan Sing Show Guess dengan media flashcard untuk memperkenalkan perbendaharaan kata bahasa Inggris pada anak TK kelompok A.

\section{KAJIAN PUSTAKA}

\section{Konsep Menulis}

Menulis merupakan merupakan aktivitas mengungkapkan gagasan, kegiatan produktif dan ekspresif sehingga penulis harus mempunyai kemampuan dalam menggunakan kosa kata, tata tulis, dan struktur bahasa (Nurgiyantoro, 2001:273). Menulis merupakan suatu kegiatan yang produktif dan ekspresif. Dalam kegiatan menulis, penulis harus trampil memanfaatkan grafologi, bahasa, dan kosa kata. Keterampilan menulis tidak datang secara otomatis, melainkan harus melalui latihan dan praktek yang banyak dan teratur. Menurut Gebhardt dan Dawn Rodrigues
(1989:1). "writing is one of the most important things you do in college"

Menulis merupakan salah satu hal paling penting yang kamu lakukan di sekolah. Gould (1989:18) Menulis adalah perilaku kreatif, perilaku menulis kreatif karena membutuhkan pemahaman atau merasakan sesuatu: sebuah pengalaman, tulisan, peristiwa.

\section{Fungsi Menulis}

Fungsi dasar menulis dalam pengajaran bahasa Indonesia adalah sebagai: (1) dasar penguasaan materi mengingat wacana dalam bentuk verbal atau tulisan; (2) sarana peningkatan pengetahuan dan keterampilan dengan pemahaman berbagai jenis pengetahuan (misalnya dengan banyak menulis pokok-pokok pikiran dalam buku dan memahami isinya akan dapat meningkatkan pengetahuan siswa); (3) sarana peningkatan kemampuan dan keterampilan untuk meraih dan mengembangkan ilmu pengetahuan teknologi, dan seni; (4) sarana penyebarluasan pemakaian bahasa Indonesia yang baik (biasanya dengan menulis dalam bentuk bahasa resmi dan baku) untuk digunakan dalam berbagai keperluan, serta (5) sarana yang menghubungkan siswa pada mata pelajaran bahasa Indonesia dengan disiplin ilmu yang lain (Muslich, 2011:121). Sedangkan menurut Bailey (2011:3) menyatakan bahwa

"The purpose of writing to discuss a subject of common interest and give the writer's view".

Dari pernyataan tersebut dapat diartikan bahwa tujuan utama menulis adalah membahas topik yang menarik dan memberikan pandangan penulis. Menurut Tompkins (1991:227) menyebutkan bahwa terdapat lima proses dalam menulis yaitu (1) prewriting, (2) drafting, (3) revising, (4) editing, and (5) publishing.

\section{METODE}

Jenis penelitian yang digunakan merupakan jenis penelitian \& pengembangan atau research and development $(\mathrm{R} \& \mathrm{D})$ yaitu suatu metode penelitian yang digunakan untuk menghasilkan produk tertentu dan menguji keefektifan produk tersebut (Sugiyono, 2008:427). Alur penelitian pengembangan modul ini menggunakan model Four-D Model. Menurut Thiagarajan, dkk. (1974:5), model pengembangan ini terdiri atas empat tahap pengembangan yaitu pendifinisian (define), perancangan (design), pengembangan 
(develop), dan penyebaran (disseminate). Dalam penelitian ini pengembangan media disederhanakan hanya sampai pada tahap pengembangan (develop), tanpa tahap penyebaran (disseminate). Instrumen pengumpulan data lembar validasi check list dan teknik catat, lembar validasi media/check list, Lembar Observasi Aktivitas Siswa, Lembar Observasi Aktivitas Guru, Lembar Soal Tes, Lembar Wawancara

\section{Teknik Penganalisisan Data}

Teknik-teknik yang digunakan dalam menganalisis data-data dalam penelitian ini dipaparkan seabagai berikut. Analisis Validitas Media, Analisis data hasil observasi aktivitas siswa, Analisis data hasil observasi aktivitas guru, Analisis tes hasil belajar siswa.

\section{Instrumen Penganalisisan Data}

Instrumen penganalisisan data untuk proses pengembangan media lembar check list, teknik catat;

a. Instrumen penganalisisan data untuk kualitas pengembangan media lembar check list;

b. Instrumen penganalisisan data untuk implementasi pengembangan media

1) lembar check list;

2) instrumen respon guru dan siswa

3) lembar observasi aktivitas guru dan siswa;

4) lembar angket guru dan siswa;

5) lembar wawancara guru dan siswa;

6) lembar tes.

\section{HASIL DAN PEMBAHASAN}

a. Validasi Isi Ahli KeSDan

Hasil penilaian validasi keSDan dapat dihitung dengan rumus jumlah skor hasil validasi dibagi jumlah skor tertinggi dikalikan $100 \%$. Jumlah skor hasil validasi sebanyak 51 dibagi dengan jumlah skor tertinggi sebanyak 56 dikalikan $100 \%$ sehingga mendapatkan hasil $91,07 \%$. Sedangkan skor validitas media dapat dihitung dengan rumus jumlah skor hasil validasi 51 dibagi jumlah aspek dalam media 14 sehingga mendapatkan hasil 3.64. Berdasarkan perhitungan di atas interprestasi skor media yang dikembangkan mendapatkan nilai 91,07 \% dengan validitas media 3.64 sehingga dapat disimpulkan bahwa kualitas media flashcard berbasis macromedia flash dari validator ke SD an memberikan validitas sangat baik dan berkualitas. b. Validasi Suara Ahli Bahasa

Hasil penilaian validasi suara dapat dihitung dengan rumus jumlah skor hasil validasi dibagi jumlah skor tertinggi dikalikan $100 \%$. Jumlah skor hasil validasi sebanyak 28 dibagi dengan jumlah skor tertinggi sebanyak 32 dikalikan $100 \%$ sehingga mendapatkan hasil $87,5 \%$. Sedangkan skor validitas media dapat dihitung dengan rumus jumlah skor hasil validasi 28 dibagi jumlah aspek dalam media 8 sehingga mendapatkan hasil 3.5. Berdasarkan perhitungan di atas interprestasi skor media yang dikembangkan mendapatkan nilai $87,5 \%$ dengan validitas media 3.5 sehingga dapat disimpulkan bahwa kualitas media flashcard berbasis macromedia flash dari validator bahasa memberikan validitas baik dan berkualitas

c. Validasi Suara Ahli Teknologi Pendidikan Hasil penilaian validasi suara dapat dihitung dengan rumus jumlah skor hasil validasi dibagi jumlah skor tertinggi dikalikan $100 \%$. Jumlah skor hasil validasi sebanyak 15 dibagi dengan jumlah skor tertinggi sebanyak 16 dikalikan $100 \%$ sehingga mendapatkan hasil $93,75 \%$. Sedangkan skor validitas media dapat dihitung dengan rumus jumlah skor hasil validasi 15 dibagi jumlah aspek dalam media 4 sehingga mendapatkan hasil 3.75 . Berdasarkan perhitungan di atas interprestasi skor media yang dikembangkan mendapatkan nilai $93,75 \%$ dengan validitas media 3.75 sehingga dapat disimpulkan bahwa kualitas media flashcard berbasis macromedia flash dari validator teknologi pendidikan dinilai sangat baik dan berkualitas.

d. Validasi Bahasa Ahli Bahasa

hasil penilaian validasi bahasa dapat dihitung dengan rumus jumlah skor hasil validasi dibagi jumlah skor tertinggi dikalikan $100 \%$. Jumlah skor hasil validasi sebanyak 36 dibagi dengan jumlah skor tertinggi sebanyak 40 dikalikan $100 \%$ sehingga mendapatkan hasil $90 \%$. Sedangkan skor validitas media dapat dihitung dengan rumus jumlah skor hasil validasi 36 dibagi jumlah aspek dalam media 10 sehingga mendapatkan hasil 3.6. Berdasarkan perhitungan di atas interprestasi 
skor media yang dikembangkan mendapatkan nilai $90 \%$ dengan validitas media 3.6 sehingga dapat disimpulkan bahwa kualitas media flashcard berbasis macromedia flash dari validator bahasa dinilai sangat baik dan berkualitas

e. Validasi Gambar Diam Ahli Teknologi Pendidikan

Hasil penilaian validasi gambar dapat dihitung dengan rumus jumlah skor hasil validasi dibagi jumlah skor tertinggi dikalikan $100 \%$. Jumlah skor hasil validasi sebanyak 30 dibagi dengan jumlah skor tertinggi sebanyak 32 dikalikan $100 \%$ sehingga mendapatkan hasil $93.75 \%$. Skor validitas media dapat dihitung dengan rumus jumlah skor hasil validasi 30 dibagi jumlah aspek dalam media 8 sehingga mendapatkan hasil 3.75. Berdasarkan perhitungan di atas interprestasi skor media yang dikembangkan mendapatkan nilai $93.75 \%$ dengan validitas media 3.75 sehingga dapat disimpulkan bahwa kualitas media flashcard berbasis macromedia flash dari validator teknologi pendidikan dinilai sangat baik dan berkualitas

f. Validasi Gambar Animasi Ahli Teknologi Pendidikan

Hasil penilaian validasi gambar animasi dapat dihitung dengan rumus jumlah skor hasil validasi dibagi jumlah skor tertinggi dikalikan $100 \%$. Jumlah skor hasil validasi sebanyak 50 dibagi dengan jumlah skor tertinggi sebanyak 56 dikalikan $100 \%$ sehingga mendapatkan hasil $89.92 \%$. Sedangkan skor validitas media dapat dihitung dengan rumus jumlah skor hasil validasi 50 dibagi jumlah aspek dalam media 14 sehingga mendapatkan hasil 3.57 . Berdasarkan perhitungan di atas interprestasi skor media yang dikembangkan mendapatkan nilai $89.92 \%$ dengan validitas media 3.57 sehingga dapat disimpulkan bahwa kualitas media flashcard berbasis macromedia flash dari validator teknologi pendidikan dinilai baik dan berkualitas.

g. Respons Siswa terhadap Penggunaan Media Flashcard Berbasis Macromedia flash

Hasil penilaian dapat dihitung dengan rumus banyaknya aktivitas siswa yang muncul 28, dibagi jumlah aktivitas keseluruhan 20, dikalikan $100 \%$ sehingga mendapatkan hasil $90 \%$. Berdasarkan perhitungan di atas presentase aktivitas siswa dalam pembelajaran menggunakan media flashcard berbasis macromedia flash mendapatkan presentase $90 \quad \% \quad$ dengan kategori siswa sangat aktif

h. Respons Guru Terhadap Penggunaan Media Flashcard Berbasis Macromedia flash hasil penilaian dapat dihitung dengan rumus banyaknya aktivitas guru yang muncul 18, dibagi jumlah aktivitas keseluruhan 20, dikalikan $100 \%$ sehingga mendapatkan hasil $90 \%$. Berdasarkan perhitungan di atas presentase respons guru dalam penerapan media flashcard berbasis macromedia flash menggunakan model TTW mendapatkan presentase $90 \%$ dengan tingkat keberhasilan baik sekali/optimal.

i. Aktivitas Siswa Terhadap Penggunaan Media Flashcard Berbasis Macromedia flash

Hasil penilaian dapat dihitung dengan rumus banyaknya aktivitas siswa yang muncul 33, dibagi jumlah aktivitas siswa keseluruhan 36 , dikalikan $100 \%$ sehingga mendapatkan hasil $91.66 \%$. Berdasarkan perhitungan di atas presentase aktivitas siswa dalam penerapan media flashcard berbasis macromedia flash menggunakan model TTW mendapatkan persentase $91.66 \%$ dengan tingkat aktivitas siswa sangat aktif.

j. Aktivitas Guru Terhadap Penggunaan Media Flashcard Berbasis Macromedia flash

Hasil penilaian dapat dihitung dengan rumus banyaknya aktivitas guru yang muncul 18 , dibagi jumlah aktivitas siswa keseluruhan 20 , dikalikan $100 \%$ sehingga mendapatkan hasil $90 \%$. Berdasarkan perhitungan di atas persentase aktivitas guru dalam penerapan media flashcard berbasis macromedia flash menggunakan model TTW mendapatkan persentase $90 \%$ dengan tingkat keberhasilan baik sekali/istimewa.

k. Hasil Belajar Siswa Terhadap Penggunaan Media Flashcard Berbasis Macromedia flash Untuk mengetahui tingkat keberhasilan siswa dalam menulis menggunakan media flash Card berbasis macromedia flash, berikut disajikan tabel yang menunjukkan perolehan nilai siswa. Nilai siswa sebelum menggunakan media dan 
sesudah menggunakan media. Untuk kegiatan ini, subjeknya adalah siswa kelas IVB yang berjumlah 25 orang. Nilai KKM pada mata pelajaran Bahasa Indonesia kelas IV adalah $\leq$ 75. Pada saat kegiatan pre test ada 8 siswa yang tidak tuntas belajar karena nilai mereka $\leq 75$, sedangkan 17 siswa lainnyanya dinyatakan tuntas belajar karena nilai mereka $\geq 75$. Secara klasikal, tingkat keberhasilan siswa sebelum menggunakan media flash Card berbasis macromedia flash dapat dihitung dengan cara jumlah siswa yang tuntas belajar 18, dibagi dengan jumlah siswa keseluruhan 25, dikalikan $100 \%$ sehingga didapatkan hasil $72 \%$. Sedangkan untuk siswa yang tidak tuntas belajar dapat dihitung dengan, jumlah siswa yang tidak tuntas belajar 7, dibagi dengan jumlah siswa keseluruhan 25, dikalikan $100 \%$ sehingga didapatkan hasil $28 \%$ dan rata-rata nilai kelas IVB adalah 74.16.

Dengan banyaknya siswa yang tidak lulus ketika kegiatan pre test dilakukan, maka pada kegiatan post test peneliti menggunakan media flash Card berbasis macromedia flash. Ada peningkatan yang signifikan pada kegiatan pre test dan post test. Pada kegiatan post test hanya ada 3 siswa yang tiak tuntas belajar, sedangkan sebanyak 22 siswa nilainya $\geq 75$ sehingga dinyatakan tuntas belajar. Nilai tertinggi pada kegiatan post test adalah 94 sedangkan nilai terendah adalah 73. Secara klasikal, tingkat keberhasilan siswa setelah menggunakan media flash Card berbasis macromedia flash dapat dihitung dengan cara jumlah siswa yang tuntas belajar 22, dibagi dengan jumlah siswa keseluruhan 25, dikalikan $100 \%$ sehingga didapatkan hasil $92 \%$. Sedangkan yang tidak tuntas belajara dapat dihitung jumlah siswa yang tidak tuntas belajar 3 , dibagi dengan jumlah siswa keseluruhan 25 , dikalikan $100 \%$ sehingga didapatkan hasil 12 $\%$ dan rata-rata nilai kelas IVB adalah 85.24.

Dari data secara umum, tingkat keberhasilan siswa kelas IVB dalam pembelajaran menulis menggunakan media flash Card berbasis macromedia flash terdapat peningkatan sebanyak $20 \%$. Sehingga dapat disimpulkan bahwa media flash Card berbasis macromedia flash layak dan efektif digunakan untuk pembelajaran menulis karena mampu memberikan peningkatan hasil belajar siwa dalam menulis.

\section{PENUTUP}

Kesimpulan

Berdasarkan hasil diskusi BAB IV dan sesuai dengan rumusan masalah dari penelitian ini, maka dapat dirumuskan kesimpulan dari kegiatan pembelajaran yaitu pada proses pengembangan menggunakan model Four-D Model terdiri atas empat tahap pengembangan yaitu Tahap pendifinisian meliputi analisis akar masalah, analisis siswa, analisis materi pelajaran menulis, analisis konsep, dan analisis perumusan tujuan pembelajaran menulis. Tahap perancangan meliputi desain awal media, penyusunan RPP, dan rancangan penerapan media (design). Tahap pengembangan mengembangkan media mulai dari proses pembuatan flashcard, proses pembuatan macromedia flash, proses pembuatan naskah, proses dubbing suara, validasi ahli, revisi media tahap I, uji coba, revisi media tahap II, dan penerapan media. Proses media ini hanya terbatas pada tahap pengembangan, sehingga tahap penyebaran tidak dilakukan.

Kualitas media meliputi (1) validasi isi oleh ahli ke SD an mendapatkan skor $91,07 \%$ dengan validitas validitas sangat baik dan berkualitas; (2) validasi suara ahli Bahasa mendapatkan skor 87,5 $\%$ dengan validitas baik dan berkualitas; (3) validasi suara ahli teknologi pendidikan mendapatkan skor mendapatkan skor 93,75\% dengan validitas dinilai sangat baik dan berkualitas; (4) validasi Bahasa Ahli Bahasa mendapatkan skor $90 \%$ dengan validitas sangat baik dan berkualitas; (5) validasi gambar diam ahli teknologi pendidikan mendapatkan skor 93,75\% dengan validitas sangat baik dan berkualitas; (6) validasi gambar diam ahli Bahasa mendapatkan skor 89.92 dengan validitas baik dan berkualitas; (7) respons siswa mendapatkan skor $90 \%$ dengan kategori siswa sangat aktif; (8) respons guru mendapatkan skor $90 \%$ dengan tingkat keberhasilan baik sekali/optimal; (9) aktivitas guru mendapatkan skor $90 \%$ dengan tingkat keberhasilan baik sekali/istimewa; (10) hasil belajar siswa pada saat pre test mendapatkan skor $72 \%$, sedangkan hasil belajar siswa pada saat posttest mendapatkan skor $92 \%$ dengan rata-rata 
nilai kelas IVB adalah 85.24. sehingga tingkat keberhasilan siswa meningkat sebanyak $20 \%$.

\section{Saran}

Dengan memperbaiki hasil penelitian, peneliti memberikan saran sebagai berikut.

1. peneliti lain melakukan penelitian lanjutan terhadap media flashcard berbasis macromedia flash sehingga media ini menjadi lebih baik;

2. guru menggunakan media flashcard berbasis macromedia flash tidak hanya pada materi meulis, melainkan bisa digunakan untuk materi menyimak dan mendengarkan;

3. guru lebih sering menggunakan media pada saat menyampaikan pelajaran agar siswa lebih termotivasi serta dapat meningkatkan hasil belajar mereka;

4. guru mencoba membuat media pembelajaran sendiri atau bersama-sama dengan siswa supaya kegiatan belajar mengajar di dalam kelas menjadi lebih bermakna.

\section{DAFTAR PUSTAKA}

Ahmadi, Abu dan Widodo Supriyono. (2003). Psikologi Belajar. Jakarta : Rineka Cipta.

Ariani, Niken dkk. (2010). Pembelajaran Multimedia di Sekolah. Jakarta: Prestasi Pustakarya.

Aqib, Zainal. (2013). Model-model Media dan Strategi Pembelajaran Konstektual (Inovatif). Bandung: Yrama Widya

Aqib, Zainal dkk. (2008). Penelitian Tindakan Kelas.Bandung: Yrama Widya.

Bailey, Stephen. (2011). Academic Writing: A Handbook For International Students. New York: Routledge.

BSNP (Badan Standar Nasional Pendidikan).

Clark, J and Paivo, A. (1991). Dual coding theory dan education. Educational psychology Review, 3 (3) halaman 149-210.

Daryanto. (2013). Media Pembelajaran. Yogyakarta: GAVA MEDIA

Djamarah, Syaiful Bahri. (2005). Guru dan Anak Didik Dalam Interaksi Edukatif. Jakarta: Asdi Mahasatya.

Elsevier Ltd. (2013). Factors Related the Utilization of Instructional Media. Education and Technology-TASET, Universitesi, Turkey: Sakarya
Gould, Erick., Robert D.Y., et.al. (1989). Act Of Writing (McGraw-Hill English Language Series)

Hariani, Sri.,dkk. (2010). Penerapan Strategi Pemetaan Struktur Teks Untuk Meningkatkan Keterampilan Berbahasa Bagi Siswa Kelas IV SDN Babatan 4 Surabaya. Surabaya: HIBAH BERMUTU Lembaga Penelitian Unesa.

Hasanal, Izatil Nur. (2014). Pengembangan Permainan Sing Show Guess Dengan Media Flashcard Untuk Memperkenalkan Perbendaharaan Kata Bahasa Inggris Pada Anak TK Kelompok A(Tesis magister pendidikan tidak dipublikasikan). Universitas Negeri Surabaya.

Hasan, Helmi,dkk. (2003). Buku Ajar Strategi Belajar Mengajar. Padang: UNP

Heinich, R., Molenda. et.al. (1993). Instructional Media And The New Technologies Of Instruction. New York: Macmillan Publishing Company.

Hidayatullah, Priyanto dkk. (2011). Animasi Pendidikan Menggunakan Flash + CD.Bandung: Informatika Bandung

Huda, Miftahul. (2013). Model-model Pengajaran dan Pembelajaran. Yogyakarta: Puataka Pelajar

Holzinger, A., Ebner, M. (2003). Interaction and Usability of Simulation \& Animation: Acase study of The Flash Technology. Rauterberg

http://id.wikipedia.org/wiki/Wikipedia:Kriteria_ga mbar_pilihan. Diunduh tanggal 18 Januari 2015 pukul 22.00 WIB.

http://id.wikipedia.org/wiki/Analisis_isi. Diunduh tanggal 22 Januari 2015 pukul 20.05 WIB

http://www.scribd.com/doc/205628660/LEMBARCATATAN-LAPANGAN\#scribd. Diunduh tanggal 23 Januari 2015 pukul 02.44 WIB

Indarti, Titik. (2008). Penelitian Tindakan Kelas (PTK) dan Penulisan Ilmiah. Surabaya: FBS UNESA.

Indriana, Dina. (2011). Alat Bantu Media Pembelajaran. Yogyakarta. DIVA press.

KBBI (Kamus Besar Bahasa Indonesia)

Mahsun. (2005). Metode Penelitian Bahasa. Jakarta: PT Raja Grafindo Persada.

Miswanto. (2011). Pengembangan Perangkat Pembelajaran IPA SD disertai media berbasis komputer dengan program macromedia flash Pada Pokok Bahasan 
Sistem Tata Surya(Tesis magister pendidikan tidak dipublikasikan). Universitas Negeri Surabaya.

Moleong, Lexy J. (2000). Metode Penelitian Kualitatif. Bandung: Remaja Rosdakarya.

Munif, Abdul. (2013). Pengembangan Media Bintang Kecil Pada Pembelajaran Kosakata Bahasa Indonesia Kelas I SD Dengan Tema Keluarga(Tesis maister pendidikan tidak dipublikasikan). Universitas Negeri Surabaya.

Munir. (2013). Multimedia konsep \& aplikasi dalam pendidikan. Bandung: ALFABETA.

Masnur, Muslich. (2011). Melaksanakan PTK Itu Mudah. Jakarta: Bumi Aksara.

Nieveen, Nienke. (1999). Prototyping to Reach Product Quality: Design Approaches and Tools in Education and Training. Dorgrecht: Netherland Kluwer Academic Publishers

Nurgiyantoro, Burhan. (2009). Penilaian Pengajaran Bahasa dan Sastra. Yogyakarta: BPFE

Nurgiyantoro, Burhan. (2001). Menulis Secara Populer. Jakarta: Pustaka Jaya

Pramono, A. (2003). Berkreasi Animasi dengan Macromedia Flash MX. Yogyakarta: Andi Offset

Rahmah, Maulida. (2013). Pengembangan Instrumen Penilaian Kualitas Media Pembelajaran Elektronika Kimia Dalam Bentuk Penilaian Skala: UPI

Resmini, Novi., dkk. (2006). Membaca dan Menulis di SD. Bandung: UPI PRESS.

Rohani, Ahmad. (1997). Media Instruksional Edukatif. Jakarta: Rineka Cipta.

Sadiman, Arif., dkk. (2008). Media Pendidikan. Jakarta: PT Grafindo Persada.

Saddhono, Kundharu dan Slamet. 2012. Meningkatkan Keterampilan Berbahasa Indonesia (Teori dan Aplikasi). Bandung: Karya Putra Darwati.

Slavin, Robert E. (2008). Psikologi Pendidikan Teori dan Praktik. Jakarta: Indeks.

Soeharto, Karti. (2010). Pendidikan Teori dan Praksis. Surabaya: Unesa University Press.

Subayani, Nataria Wahyuning. (2013). Mereduksi Miskonsepsi IPA Menggunakan Media Animasi Adobe Flash Di Sekolah Dasar(Tesis magister pendidikan tidak dipublikasikan). Universitas Negeri Surabaya.
Sudirman. (2011). Animasi Kartun Lucu dengan FLASH CS5. Palembang: Maxikom.

Sudjana, Nana dan Ahmad Rivai. (2010). Media Pengajaran. Bandung: Sinar Baru Algasindo.

Sudjana, Nana dan Ahmad Rivai. (2005). Media Pengajaran. Bandung: Sinar Baru Algasindo.

Sugiyono. (2008). Metodologi Penelitian Pendidikan. Bandung: ALFABETA.

Sugiyono. (2009). Metode Penelitian Kuantitatif dan Kualitatif. Bandung: Alfabeta

Susilana, Rudi., dkk. (2009). Media Pembelajaran. Bandung: Wacana Prima.

Suyatno. (2004). Teknik Pembelajaran Bahasa Dan Sastra. Surabaya: SIC.

Tarigan, Henry Guntur. (1986). Menulis sebagai Suatu Keterampilan Berbahasa. Bandung: Angkasa.

Taum, Yoseph Yapi. (2011). Studi Sastra Lisan: Sejarah, Teori, Metode dan Pendekatan. Yogyakarta: Lamalera.

Thiagarajan, Semmel, DS \& Semmel M.I. (1974). Instructional Development for Training Teacher of Exceptional Children. A Source Book. Blomington: Center for Innovation on Teaching the Handicapped.

Tompkins, G.E. \& Hoskinsson, K. (1991).Leanguage Arts Content And Teaching Strategis. New York: Macmillan College Publishing Company.

Trianto. (2007). Mengembangkan Model Pembealajaran Tematik. Jakarta:PT Prestasi Pustaka.

Wirastiwi, Wendri. (2013). Pengembangan Modul IPS Berwawasan Pendidikan Karakter Pada Materi Proklamasi Kemerdekaan Indonesia Untuk Kelas V Sekolah Dasar(tesis magister pendidikan tidak dipublikasikan). Universitas Negeri Surabaya.

Yulianto, Bambang dkk. (2009). Model Pembelajaran Inovatif Bahasa Indonesia. Surabaya: Unesa University Press. 